\title{
Enzymatic profile of different parts of yam (Dioscorea) tuber during storage
}

\section{Soumaila Dabonne, Martin Kouakou DJE, Hubert Kouassi Konan and Lucien Patrice Kouame}

\author{
Laboratory of Biochemistry and Food Science and Technology \\ University of Abobo-Adjamé 02 BP 802 Abidjan 02 (Côte D'Ivoire) \\ Corresponding author : Soumaila Dabonné : sdabonne@yahoo.fr
}

\begin{abstract}
The purpose of this survey was to investigate the effect of storage on polysaccharidases (amylases, cellulases and inulase), phosphatases and pNP-glycosidase ( $\alpha$-glucosidases, $\alpha-$ fucosidases, $\alpha$-galactosidase, $\beta$-glucosidases and $\beta$-galactosidases, $\alpha$-mannosidases) activities from different tuber parts of "Kangba" and "Krenglè" cultivars belonging to the Dioscorea cayenensis-rotundata complex species. These two cultivars did not contain $\alpha$-glucosidase, $\alpha-$ fucosidase, $\alpha$-galactosidase, $\beta$-glucosidase, $\beta$-galactosidase and inulase activities. The detected activities in the different part of yams tuber were those of $\alpha$-mannosidase, phospatase, amylases and cellulases activities. Amylase and cellulase activities increased in the different tuber parts of yams during the post-harvest storage, whereas a-mannosidases, phospatases decreased in these same parts. The distal part of yam tuber had the most elevated activities whatever the cultivar was.
\end{abstract}

Keywords : Crops preservation, Cultivars, Enzymes, Food safety.

\section{INTRODUCTION}

Yam belongs to the Disocorea genus and are staple foods of cultural, economic and nutritional importance in the tropics which produce edible starchy storage tubers (Sefa-Dedeh and Afoakwa, 2002). It constitutes one of the mostly cultivated and consumed species in Côte d'ivoire (Doumbia et al., 2006). Yam is mainly composed of starch $(75-84 \%$ of dry weight) with small amounts of proteins, lipids and most vitamins and very rich minerals (Lasztify et al, 1998). The yam protein also showed a better amino acid balance for human nutrition (Bradburg, 1998 ; Marcus et al., 1988). Indeed, fresh yams are difficult to store and are subject to deterioration during storage (Afoakwa and Sefa-Dedeh, 2001). The storage difficulties brought losses of $25 \%$ of the tuber production (Girardin, 1996). These losses are due to physical and physiological causes. The physical factors were temperature, relative humidity and the injuries. As for physiological factors, they were constituted of breathing, dehydration and germination (Onwueme, 1978). Indeed, the metabolic activity is closely linked to those of the enzymes during the germination (Adesuyi, 1978). These activities were little studied in the whole yam tubers. Besides, Diopoh and Kamenan (1981) and Houvet et al. (1982a) carried out the works on the amylases activities in the yams whole tubers. To our
Knowledge, there are no previous reports on the enzymes activities in different tuber parts of yams during the storage.

This study was conducted on the one hand highlight the presence of some enzymatic activities in the yam tuber and secondly to determine the evolution of these activities in different parts of the tuber during storage.

\section{MATERIALS AND METHODES}

Plant material : Two cultivars of yams, Dioscorea cayenensis rotundata complex ("Krenglè" and "Kangba"), were used in the present study. The tubers of these yams cultivars were measured about $44.07 \pm 4.46 \mathrm{~cm}$. They were harvested at maturity from fields in the Centre of Côte d'Ivoire. They were immediately transported in a heap aired store and stored under prevailing tropical ambient conditions $\left(26.56^{\circ} \mathrm{C} \pm 3^{\circ} \mathrm{C}\right.$ and $\left.82 \% \pm 5 \% \mathrm{RH}\right)$ for a period of 6 months of subsequent experiments.

Sampling : Four (4) tubers of each yam cultivar were randomly made a pick, every two months during for up to six (6) months. These yams were washed, then cut in three equal parts and giving three lots of yams made up the proximal parts (head of tuber), the median parts (middle of tuber) and the distal parts (tail of tuber) 
Enzyme extraction: Each lot of tuber part $(50 \mathrm{~g})$ was ground in a grinder MOULINEX mark in $20 \mathrm{ml}$ of $\mathrm{NaCl} 0.9 \%(\mathrm{w} / \mathrm{v})$. The homogenate was subjected to sonication using a TRANSSONIC T420 for $10 \mathrm{~min}$ and then centrifuged at $6000 \mathrm{rpm}$ for $30 \mathrm{~min}$. The gotten supernatant was used as the crude extract and conserved at $4{ }^{\circ} \mathrm{C}$.

Enzyme assay: Acid phosphatase activities were carried out in a total volume of $210 \mu \mathrm{l}$, containing 125 $\mu \mathrm{l}$ of sodium acetate buffer (100 mM ; pH 5.0), $50 \mu \mathrm{l}$ of enzyme crude extract and $75 \mu \mathrm{l}$ of substrate $p N P P$ $(5 \mathrm{mM})$. The reaction mixture was incubated at $37^{\circ} \mathrm{C}$ for $10 \mathrm{~min}$, then $2 \mathrm{ml}$ of $\mathrm{Na} 2 \mathrm{CO} 32 \%(\mathrm{w} / \mathrm{v})$ were added to stop the reaction and absorbances were measured at $410 \mathrm{~nm}$ using a spectrophotometer SPECTRONIC. Para-nitrophenol $(p N P)$ was used as standard. Under the above experimental conditions, one unit of enzyme activity was defined as $1 \mu \mathrm{mol}$ of $p N P$ released per min. Specific activity was defined as the units of enzyme activity per mg of protein.

Under the standard test conditions, pNPglycosidases activities were measured by the release of $p$-nitrophenol from the substrate $p$-nitrophenylglycopyranoside. An assay mixture $(210 \mu \mathrm{l})$ containing $125 \mu \mathrm{l}$ of sodium acetate buffer $(100 \mathrm{mM}$; $\mathrm{pH} 5.0), 50 \mu \mathrm{l}$ of enzyme crude extract and $75 \mu \mathrm{l}$ of substrate $\quad p$-nitrophenyl-glycopyranoside, was incubated at $37^{\circ} \mathrm{C}$ for $10 \mathrm{~min}$. The control contained all reactants except the enzyme. The reaction was stopped by the addition of sodium carbonate $(2 \mathrm{ml})$ at a concentration of $1 \mathrm{M}$, and absorbance of the reaction mixture was measured at $410 \mathrm{~nm}$. Finally, specific activity has been determined such as in the previous case.

Polysaccharidases activities were assayed by the dinitrosalicylic acid procedure (Bernfeld, 1955), using $1 \%$ (w/v) polysaccharide (carboxymethylcellulose, inulin and starch) as substrate. The enzyme $(50 \mu \mathrm{l})$ was incubated for $30 \mathrm{~min}$ at $37^{\circ} \mathrm{C}$ with $170 \mu \mathrm{l}$ buffer (100 mM acetate, $\mathrm{pH} 5.0$ ) and $80 \mu$ polysaccharide. The reaction was stopped by addition of $300 \mu \mathrm{l}$ dinitrosalicylic acid and heating in boiling water for 5 min. The absorbance was read at $540 \mathrm{~nm}$ after cooling on ice for $5 \mathrm{~min}$.

One unit of enzyme activity was defined as the amount of enzyme capable of releasing one $\mu \mathrm{mol}$ of $p$-nitrophenol or glucose per min under the defined reaction conditions. Specific activity was expressed as units per $\mathrm{mg}$ of protein ( $\mathrm{U} / \mathrm{mg}$ of protein).
Protein assays: Protein concentrations were determined by method of Lowry et al. (1951) using bovine serum albumin as a standard.

Statistical analysis: All analyses were performed in triplicates. Statistical significance was established using Analysis of Variance (ANOVA) models to estimate the effect of storage period on enzymes activities of different parts of yam tubers. Means were separated according to Duncan's multiple range analysis $(P \leq 0.01)$, with the help of the software Statistica 7.1 (StatSoft Inc, Tulsa USA Headquarters).

\section{RESULTS}

Acid phosphatases and pNP-glycosidases: Phosphatases activities detected in the different parts of yam tuber of Dioscorea cayenensis-rotundata complex species "Kangba" cultivar whatever the storage time is (Fig. 1).These activities decreased during storage. The most elevated phospahatase activity was observed in the distal part of "Kangba" cultivar tuber, followed by the median and proximal part. On the other hand, no $\alpha$-glucosidases, $\alpha-$ fucosidases, $\alpha$-galactosidase, $\beta$-glucosidases and $\beta$ galactosidases activity was observed during the storage. a-mannosidase activitiy, present in distal part totally disappeared after 2 months of storage. "Krenglè", another cultivar of the Dioscorea cayenensis-rotundata also exhibited phosphatase and a-mannosidase activities during storage. Phosphatase activity was present in all parts of the tuber and then decreased during conservation. amannosidase was only detected in median and distal part (Fig. 2). a-mannosidase also decreased during storage to vanish at the end of preservation period. The distal part of "Krenglè" tuber contained statistically at 0.01 level the highest $\alpha$-mannosidase and phosphatase activites. As for the variety "Kangba", "Krenglè" contained any no a-glucosidase, $\alpha$-fucosidase, $\alpha$-galactosidase, $\beta$-glucosidase and $\beta$ galactosidase activity.

Polysaccharidases activities: Amylase, inulinase and cellulose activities were monitored in the different part of the tuber during preservation. A complete absence of inulinase was noted in all part of the tubers for the duration of conservation whatever the variety was. However, all parts of the two yam varieties studied contained both amylase and cellulase activities. A general increase of two the enzymatic activities were observed during the conservation. The highest amylase and invertase activities were observed in the distal parts of the tubers in the post-harvest conservation (fig. 3-6). 
Agric. Biol. J. N. Am., 2011, 2(4): 591-597

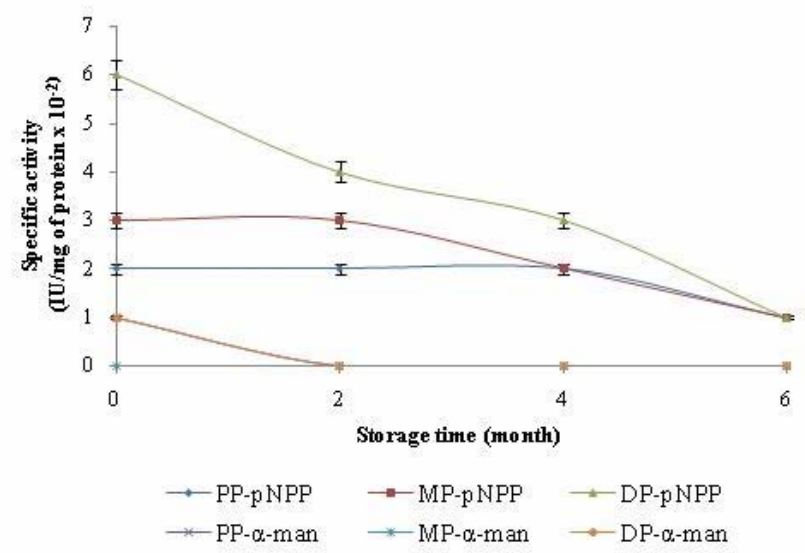

Fig 1: Phosphatase and a-mannosidase activities in the different parts of yam Dioscorea cayenensis-rotundata cultivar "Kangba" tuber during the post-harvest storage.

PP: proximal part; MP: median part; DP: distal part

a-man : $\alpha$-mannosidase activity ; $p$ NPP : phosphatase activity

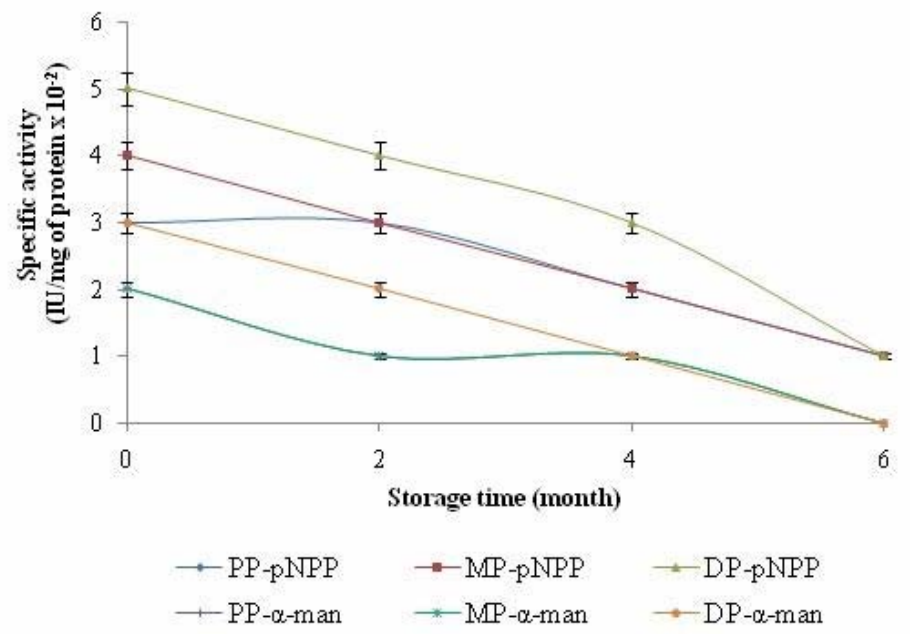

Fig 2: Phosphatases and $\alpha$-mannosidases activities in the different tuber parts of yam Dioscorea cayenensisrotundata cultivar "Krenglè" during the post-harvest storage.

PP: proximal part; MP: median part ; DP: distal part

a-man: $\alpha$-mannosidase activity ; pNPP: phosphatase activity 
Agric. Biol. J. N. Am., 2011, 2(4): 591-597

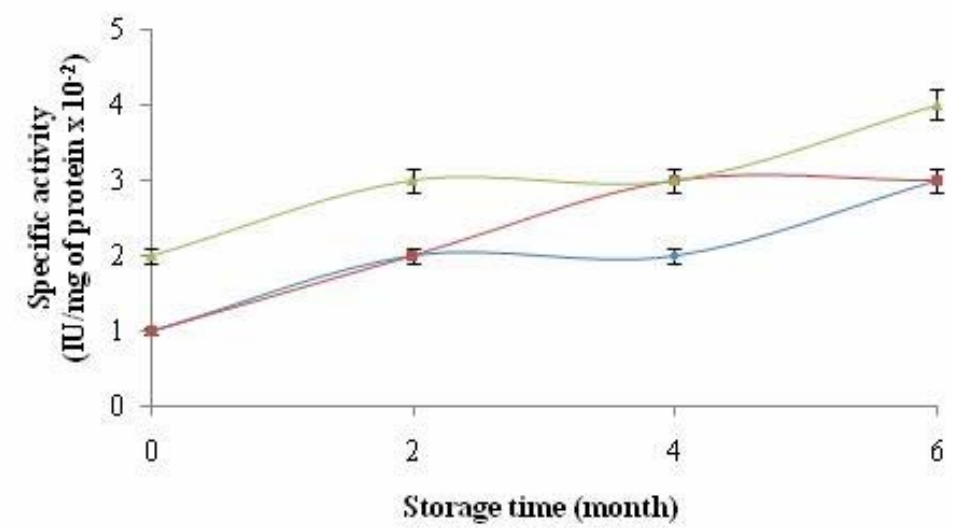

$\rightarrow \mathrm{PP} \quad \rightarrow-\mathrm{MP} \quad \rightarrow \mathrm{DP}$

Fig 3 : Amylase activity in the different tuber parts of yam Dioscorea cayenensis-rotundata cultivar "Kangba" during the post-harvest storage.

PP: proximal part; MP: median part; DP: distal part

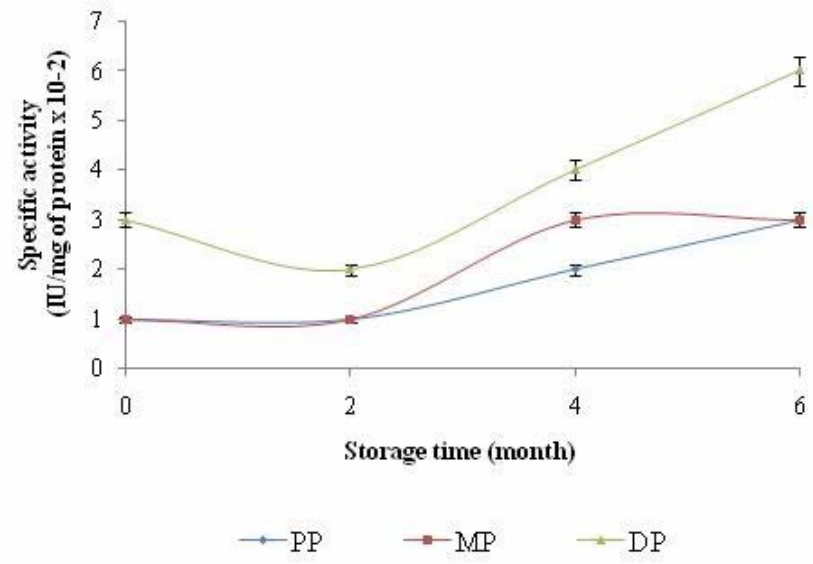

Fig 4 : Cellulase activity in the different parts of yam Dioscorea cayenensis-rotundata cultivar "Kangba" tuber during the post-harvest storage.

PP: proximal part; MP: median part; DP: distal part 


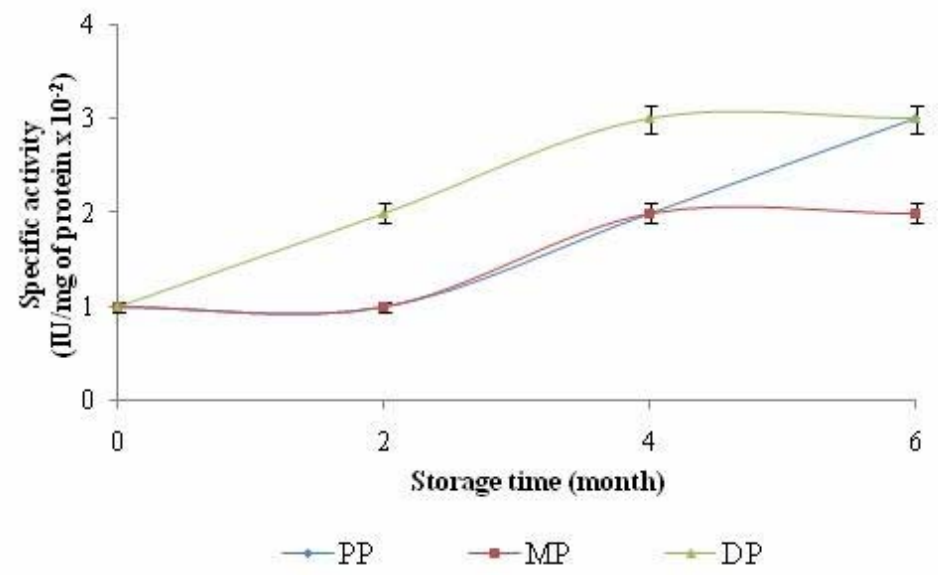

Fig 5 : Amylase activity in the different tuber parts of yam Dioscorea cayenensis-rotundata cultivar "Krenglè" during the post-harvest storage.

PP: proximal part; MP: median part; DP: distal part

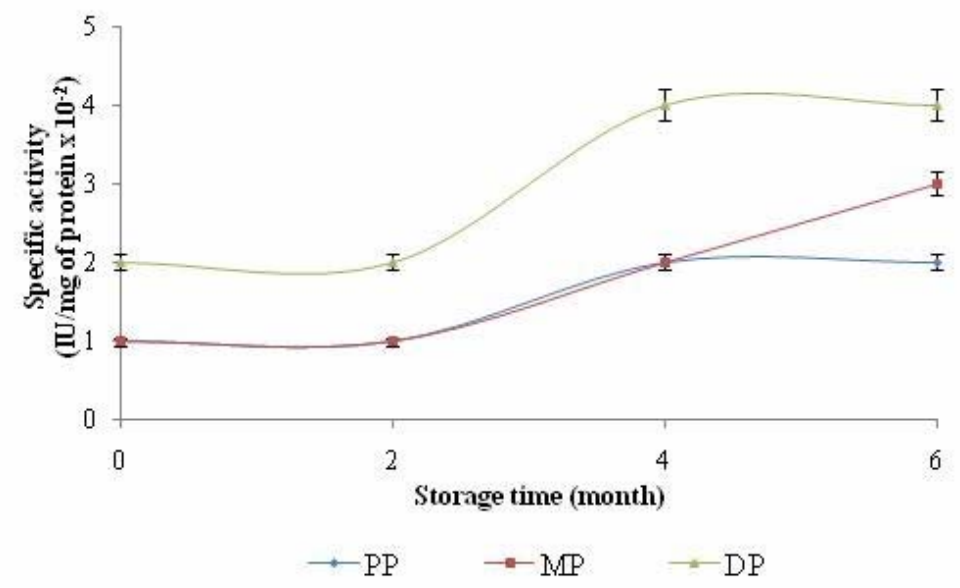

Fig 6 : Cellulase activity in the different parts of yam Dioscorea cayenensis-rotundata "cultivar Krenglè" tuber during the post-harvest storage.

PP: proximal part; MP: median part; DP: distal part 


\section{DISCUSSION}

The behavior of various enzyme activities observed during this study mainly due to the physiological role of enzymes. Specific substrates of these enzymes also play an important role. Most of these substrates are found in yam tuber. Thus, the strong presence of phosphatase activity in the different tuber parts of yam during the storage could probably be the consequence of the use of the acid phosphate as supplier of inorganic phosphate $(\mathrm{Pi})$ during the phosphorolyse as Kamenan (1984) showed it for the tubers of yam Dioscorea cayenensis-rotundata species. The decline in activity during storage phos may result from the strong depletion of phosphorylated macromolecules in the constitution of yam tuber.

The slight $\alpha$-mannosidase activity observed in the two varieties of yam is linked to the presence of polymer of mannose ranging from $93.90 \%$ to $95.40 \%$ of mucilage content in the yam tuber (Yi-Chung et.al. 2004). would intervene in the hydrolysis of these molecules. a-mannosidases is involved in the hydrolysis of mucilage explaining its decrease during storage and the increasing occurrence of mannose residues. This enzymatic activity decreases in parallel and eventually vanishes for lack of substrate.

Starch and cellulose are two polymers of glucose which are major constituents of yam tuber. They are the target substrates of amylase and cellulase respectively. These enzymes are involved in the metabolic and physiological activities of the yam tubers during the storage like germination according (Ikediobi and Oti 1983). According to Gonnety et al. (2007), the hydrolysis of the starch can occur by two ways. The amylase and the phosphorylase ways. The gradual increase in amylase activity demonstrates the dominance of the amylase way as Kouadio (2004) stipulated on the tubers of taro Xanthosoma spp species cultivar "Atoumbou Orono" during the post-harvest storage. The increase of cellulase activity causes the progressive degradation of cellulose, which is the main component of fiber in the tuber (Gohl, 1982 ; Kouadio, 2004). The predominance of amylase and cellulase activities would be responsible for the decrease in content of the potato starch and fiber (Diopoh and Kamenan, 1981). However, after six months of storage the content of cellulose and starch is still sufficient to maintain a positive growth of these two enzymes in all the parts of the tuber.
Many enzymatic activities are not produced in the yam tuber during storage. Among them, the inulinase, specific for inulin a fructose polymer. It is not produced by plants such as yams that make and store starch (Traynor et al., 2006).

$\alpha$-fucosidase, $\alpha$-galactosidase, $\beta$-galactosidase and $\beta$-glucosidase activities were note detected during the storage. It is also probably due to the absence of macromecules containing these residues in yam tuber. $\alpha$-glucosidase logically hydrolyses maltose and the maltodextrins that are the last products of the starch hydrolysis by amylase. But it seems that during the six months of storage enough maltose and maltodextrin was not produce to allow expression of a-glucosidase.

\section{CONCLUSION}

This study reveals a selective presence of enzymatic activity in the tuber of yam in its conservation. Phosphatase, amylase, cellulase and mannosidase activities are the best expressed activities. Phosphatase and mannosidase decreased while amylase and increased in the yam tuber during the storage. All detected enzymatic activities were more elevated in the distal tuber parts of yam tuber what ever the variety was.

\section{REFERENCES}

Adesuyi S. A. (1978). The application of advanced technology to the improvement of yam storage. nternational Seminar on yam. Buea, Cameroon. October 1-6, Proceedings pp . 387-398. Cf. Miège, Lyonga. 1982, pp.312-319.

Afoakwa E.O., Sefa-Dedeh S. (2001). Chemical composition and quality changes in trifoliate yam Dioscorea dumetorum tubers after harvest. Food Chemistry 75: 85-91.

Bernfeld P. (1955). Amylase $\alpha$ and $\beta$. Methods in enzymology 1.S. P. Colswick and N.O.K., (Eds). Academic Press Inc, New-York. pp. 149-154.

Bradbury j. H. (1988). The chemical composition of tropical root crops. ASEAN (Association of south East Asian Nations). Foods journal 4: 3-13.

Diopoh J. and Kamenan A. (1981). Distribution de l'amylase, de la phosphorylase et de la phosphatase acide dans quelques dioscoréacées (Ignames) de Côte d'Ivoire. Physiologie Végétale. 19 :401-405.

Doumbia S., Touré M., Mahyao A. (2006). Commercialisation de l'igname en Côte d'Ivoire : Etat actuel et perspectives d'évaluation. Cahier d'étude et de recherche francophone pour l'Agriculture 15: 273277. 
Girardin O. (1996). Postharvest technology of the yam: a study of improved traditional storage in Côte d'Ivoire. Thèse, Ecole Polytechnique Fédérale Zurich, Suisse, $\mathrm{n}^{\circ}$ 11710. $298 \mathrm{p}$.

Gohl B. (1982). Les aliments du bétail sous les tropiques. Collection FAO (12). Données sommaires et valeurs nutritives. Fondation internationale pour la science, Stockholm, Suède, $143 \mathrm{p}$.

Gonnety T. J., Niamké S., Faulet M. B., Kouadio E. J. P. N., Kouamé L. P. (2007). Purification, kinetic properties and physicochemical characterization of a novel acid phosphatase (AP) from germinating peanut (arachis hypogaea) seed. The Italian Journal of Biochemistry 56:149-157.

Houvet D., Diopoh J., Ketekou F. S., Marchis M. G. (1982a). Effets de la température sur les activités amylasiques des tubercules d'Igname. Physiologie. Végétale. 20 : 443-450

Ikediobi C., Oti E. (1983). Some biochemical changes associated with post-harvest storage of white yam (Dioscorea rotundata) tubers. Journal of Food Science and. Agriculture 34: 1123-1129

Kamenan A. (1984). Purification and physico-chemical properties of three acid phosphatases Dioscorea rotundata cayenensis.Thesis d'état es-sciences physiques, University of Cocody. Côte d'Ivoire. 134 p.

Kouadio N. E. J. P. (2004). Contribution to the study of the tuber of taro Xanthosoma spp. Var. "ATOUMBOU
ORONO.Doctorat de 3ème cycle en Sciences et Technologie des aliments. Université d'Abobo-Adjamé. Abidjan Côte d'Ivoire. 103 p.

Lasztity, Hidvegi M., Bata, A. (1988). Saponins in food. Food Reviews International. 14: 371-390.

Lowry, O.H., Rosebrough, N.J., Farr A. L. \& Randall, R. J. (1951). Protein mesurement with the folin-phenol reagent. J. Biol. Chem. 193 : 256-275.

Marcus, D. I., Thomas, c., Rodriguez, c., Sunberkoff, K., Tasi, J.S., Strfaci, J.A. (1988). Increased peroxideratoin and reduced antioxidant enzyme activity in alzheimer's disease. Experimental Neurology $150: 40-44$

Onwueme I. C. (1978). The Tropical Tuber Crops: yam, cassava, sweet patato and cocoyams. (Eds) John Wiley and Sons. New York : Chichester. Toronto: Brisbane, $234 \mathrm{p}$.

Sefa-Dedeh S., Afoakwa E. O. (2002). Biochemical and textural changes in trifoliate yam Dioscorea dumetorum tubers after harvest. Food Chemistry 79: 27-40.

Traynor J., Mactier R., Geddes C., Fox J. (2006). How to measure renal function in clinical practice. British Medical Journal 333: 733-737.

Yi-Chung F., lin-Huei A. F., Pau-Yau H. (2004). Quantitative analysis of allantoin and allantoic acid in yam tuber, mucilage, skin and bulbil of the Dioscorea species. Food Chemistry 94: 541-549. 